\title{
Design and evaluation of sustained release bilayer tablets of propranolol hydrochloride
}

\author{
CHINAM NIRANJAN PATRA* \\ ARETHI BHARANI KUMAR \\ HEMANT KUMAR PANDIT \\ SATYA PRAKASH SINGH \\ MEDURI VIMALA DEVI \\ P. G. Department of Pharmaceutics \\ College of Pharmaceutical Sciences \\ Berhampur-760002 \\ Orissa, India
}

\begin{abstract}
The objective of the present research was to develop a bilayer tablet of propranolol hydrochloride using superdisintegrant sodium starch glycolate for the fast release layer and water immiscible polymers such as ethylcellulose, Eudragit RLPO and Eudragit RSPO for the sustaining layer. In vitro dissolution studies were carried out in a USP 24 apparatus I. The formulations gave an initial burst effect to provide the loading dose of the drug followed by sustained release for $12 \mathrm{~h}$ from the sustaining layer of matrix embedded tablets. In vitro dissolution kinetics followed the Higuchi model via a non-Fickian diffusion controlled release mechanism after the initial burst release. FT-IR studies revealed that there was no interaction between the drug and polymers used in the study. Statistical analysis (ANOVA) showed no significant difference in the cumulative amount of drug release after $15 \mathrm{~min}$, but significant difference $(p<0.05)$ in the amount of drug released after $12 \mathrm{~h}$ from optimized formulations was observed.
\end{abstract}

Keywords: propranolol hydrochloride, bilayer tablets, sodium starch glycolate, water immiscible polymers, statistical analysis

Propranolol hydrochloride, a non-selective beta-adrenergic blocker, has been widely used in the treatment of hypertension, angina pectoris, pheochromocytoma and cardiac arrhythmias (1). Because of its relatively short plasma half-life, patients are routinely asked to take propranolol hydrochloride in divided daily doses, once every 6 to $8 \mathrm{~h}$. Such frequent drug administration may reduce patient compliance and therapeutic efficacy (2). In recent years, slow or sustained release formulations of propranolol hydrochloride have become available with claims that these formulations maintain beta adrenoreceptor blockade throughout a $24 \mathrm{~h}$ period and enable the drug to be given once daily (3).

The multilayered tablet concept has been long utilized to develop sustained release formulations. Such a tablet has a fast releasing layer and may contain bi- or triple layers

* Correspondence, e-mail: patro_niranjan@rediffmail.com 
to sustain the drug release (4). The pharmacokinetic advantage relies on the fact that drug release from fast releasing granules leads to a sudden rise in the blood concentration. However, the blood level is maintained at steady state as the drug is released from the sustaining granules. Among the different polymers, Eudragit $(5,6)$ and ethylcellulose (7-11) have been used successfully to obtain appropriate sustained release matrix formulations of different materials. The present study aims at formulating bilayered tablets of propranolol hydrochloride with a fast release layer using sodium starch glycolate and a sustaining layer using hydrophobic polymers like ethylcellulose, Eudragit RLPO and Eudragit RSPO.

\section{EXPERIMENTAL}

\section{Materials}

Propranolol hydrochloride was obtained as a gift sample from Natco Pharma, India. Ethylcellulose $(15 \mathrm{cP})$ was procured from Genuine Chemicals, India. Eudragit RLPO [poly (ethyl acrylate, methyl methacrylate, trimethylaminoethyl-methacrylate chloride)(1:2:02)] and Eudragit RSPO [poly(ethyl acrylate, methyl methacrylate, trimethylamino methyl methacrylate chloride) (1:2:01)] were procured from S D Fine Chemicals, India. Starch was obtained from Meghana Products, India, talc was procured from Swastik Pharmaceuticals, India, and magnesium stearate was procured from Nice Chemicals, India. Other materials and solvents used were of analytical grade.

\section{Preparation and characterization of bilayer tablets}

The bilayer tablets of propranolol hydrochloride were prepared by the wet granulation method. The drug and polymers for both fast release and sustaining layer were passed through a 180- $\mu \mathrm{m}$ sieve before their use in the formulation.

Formulation of the fast release layer. - The dose in the formulation for fast release was $25 \mathrm{mg}$, the maintenance dose or sustained dose $(55 \mathrm{mg})$ of propranolol hydrochloride was calculated as per the reported method $(12,13)$. The fast release granules were prepared by wet granulation technique by blending propranolol hydrochloride uniformly with sodium starch glycolate using starch paste $(10 \% \mathrm{~m} / \mathrm{m})$ as binder as per the formulae given in Table I. The cohesive mass obtained was passed through a $1000 \mu \mathrm{m}$ sieve, dried at $60{ }^{\circ} \mathrm{C}$ for $1 \mathrm{~h}$ to give a moisture content of $4-6 \%$, determined on an IR moisture balance (Macro Scientific Works, India). The granules were again passed through a $1000-\mu \mathrm{m}$ screen to break up agglomerates. The granules were mixed with talc and magnesium sterate.

Formulation of the sustained release layer. - The sustaining granules were formulated by the wet granulation technique, mixing propranolol hydrochloride uniformly with Eudragit RLPO, Eudragit RSPO or ethylcellulose. Lactose was mixed with the above drug and polymer mixture. Starch paste $(10 \% \mathrm{~m} / \mathrm{m})$ was used as binder as per the formulae given in Table II. The sustaining granules were also subjected to similar processing steps as the fast releasing granules. 
Ch. Niranjan Patra et al.: Design and evaluation of sustained release bilayer tablets of propranolol hydrochloride, Acta Pharm. 57 (2007) 479-489.

Table I. Formulation of the fast release layer

\begin{tabular}{lc}
\hline \multicolumn{1}{c}{ Ingredient } & Quantity for a single tablet $(\mathrm{mg})$ \\
\hline Propranolol hydrochloride & 25 \\
Sodium starch glycolate & 2.5 \\
Starch paste $(10 \%, m / m)$ & 8 \\
Magnesium stearate & 1 \\
Talc powder & 1 \\
\hline
\end{tabular}

Characterization of granules. - Prior to compression, granules were evaluated for their characteristic parameters, such as tapped density, Carr's index and angle of repose (15).

Carr's compressibility index was calculated from the bulk and tapped densities (14) using a digital tap density apparatus (Electrolab Ltd, India).

Compression of bilayer tablet. - The quantity of granules for the sustained release layer was compressed lightly using a single punch-tableting machine (Cadmach Machinery Co Pvt. Ltd., India) equipped with 6.5-mm round, flat and plain punches. Over this compressed layer, the required quantity of the fast release layer was placed and compressed to obtain hardness in the range of $5-7 \mathrm{~kg} \mathrm{~cm}^{-2}$ to form a bilayer matrix tablet.

Physical tests for the bilayer tablets. - Standard physical tests for the bilayer matrix tablets were performed (16) and average values were calculated. Mass variation was determined by weighing 20 tablets individually, the average mass was calculated and the percent variation of each tablet was calculated. Hardness was determined by taking 6 tablets from each formulation using a Monsanto hardness tester (Electrolab Pvt. Ltd., In-

Table II. Formulation of the sustained release layer

\begin{tabular}{|c|c|c|c|c|c|c|c|c|c|}
\hline \multirow{3}{*}{ Ingredient } & \multicolumn{9}{|c|}{ Mass per tablet $(m g)$} \\
\hline & \multirow{2}{*}{$\begin{array}{c}\text { EC } \\
1: 0.5\end{array}$} & \multirow{2}{*}{$\begin{array}{l}\text { EC } \\
1: 1\end{array}$} & \multirow{2}{*}{$\begin{array}{c}\text { EC } \\
1: 1.5\end{array}$} & \multicolumn{3}{|c|}{ Eudragit RSPO } & \multicolumn{3}{|c|}{ Eudragit RLPO } \\
\hline & & & & 1:0.5 & $1: 1$ & $1: 1.5$ & 1:0.5 & $1: 1$ & $1: 1.5$ \\
\hline $\begin{array}{l}\text { Propranolol } \\
\text { hydrochloride }\end{array}$ & 55 & 55 & 55 & 55 & 55 & 55 & 55 & 55 & 55 \\
\hline Ethyl cellulose & 27.5 & 55 & 82.5 & - & - & - & - & - & - \\
\hline Eudragit RSPO & - & - & - & 27.5 & 55 & 82.5 & - & - & - \\
\hline Eudragit RLPO & - & - & - & - & - & - & 27.5 & 55 & 82.5 \\
\hline Lactose & 64.5 & 37 & 9.5 & 64.5 & 37 & 9.5 & 64.5 & 37 & 9.5 \\
\hline $\begin{array}{l}\text { Starch paste } \\
(10 \%)\end{array}$ & 14 & 14 & 14 & 14 & 14 & 14 & 14 & 14 & 14 \\
\hline Talc & 2 & 2 & 2 & 2 & 2 & 2 & 2 & 2 & 2 \\
\hline $\begin{array}{l}\text { Magnesium } \\
\text { stearate }\end{array}$ & 1 & 1 & 1 & 1 & 1 & 1 & 1 & 1 & 1 \\
\hline
\end{tabular}


Ch. Niranjan Patra et al.: Design and evaluation of sustained release bilayer tablets of propranolol hydrochloride, Acta Pharm. 57 (2007) 479-489.

Table III. In-vitro dissolution kinetics of propranolol hydrochloride

\begin{tabular}{lcccc}
\hline \multirow{2}{*}{ Formulation } & \multicolumn{3}{c}{ Drug release kinetics $(R)$} & \multirow{2}{*}{$\begin{array}{c}\text { Peppas release } \\
\text { exponent }(n)\end{array}$} \\
\cline { 2 - 4 } & Zero-order & First-order & Higuchi type & 0.745 \\
\hline RSPO 1:0.5 & 0.984 & 0.969 & 0.993 & 0.672 \\
RSPO 1:1 & 0.965 & 0.964 & 0.994 & 0.610 \\
RSPO 1:1.5 & 0.979 & 0.952 & 0.988 & 0.718 \\
RLPO 1:0.5 & 0.991 & 0.964 & 0.997 & 0.649 \\
RLPO 1:1 & 0.959 & 0.939 & 0.994 & 0.604 \\
RLPO 1:1.5 & 0.979 & 0.952 & 0.988 & 0.673 \\
EC 1:0.5 & 0.983 & 0.969 & 0.995 & 0.585 \\
EC 1:1 & 0.967 & 0.945 & 0.991 & 0.589 \\
EC 1:1.5 & 0.977 & 0.963 & 0.990 & \\
\hline
\end{tabular}

dia) and the average of pressure $\left(\mathrm{kg} \mathrm{cm}^{-2}\right)$ applied for crushing the tablet was determined. Friability was determined by first weighing 10 tablets after dusting and placing them in a friability tester (Electrolab Pvt. Ltd., India), which was rotated for 4 min at $25 \mathrm{rpm}$. After dusting, the total remaining mass of the tablets was recorded and the percent friability was calculated.

Drug content uniformity. - Ten tablets were finely powdered and an amount equivalent to $40 \mathrm{mg}$ of propranolol hydrochloride was accurately weighed and transferred to a $100 \mathrm{~mL}$ volumetric flask, then $70 \mathrm{~mL}$ of methanol was added. The flask was shaken for $10 \mathrm{~min}$. Finally, the volume was made up to the mark with methanol. The mixture was then filtered and $1 \mathrm{~mL}$ of the filtrate was suitably diluted with methanol to obtain a solution containing about $40 \mu \mathrm{g} \mathrm{mL} \mathrm{mL}^{-1}$ of propranolol hydrochloride and analyzed for propranolol hydrochloride content (17) at $290 \mathrm{~nm}$ using a double beam UV/Visible spectrophotometer (Elico Ind Ltd, India) and methanol as blank.

\section{In vitro dissolution}

Release of propranolol hydrochloride was determined using a USP 24 (17) six stage dissolution rate test apparatus 1 (Labindia Instruments Pvt. Ltd, India) at $50 \mathrm{rpm}$. The dissolution was studied using $900 \mathrm{~mL}$ of simulated gastric fluid (without enzyme, $\mathrm{pH}$ 1.2) for the first $2 \mathrm{~h}$ and followed by simulated intestinal fluid (without enzyme, $\mathrm{pH} 7.2$ ) for the remaining hours (17). The temperature was maintained at $37 \pm 0.2^{\circ} \mathrm{C}$. The sample $(5 \mathrm{~mL})$ was withdrawn at different time intervals, i.e. 5, 15, 30, 60, 120, 180, 240, 300, 360, 480, 600 and $720 \mathrm{~min}$, filtered through Whatman filter paper (Auroco Pvt Ltd, Thailand) and replaced by an equal volume of dissolution medium. Samples were suitably diluted and analyzed for propranolol hydrochloride content at $290 \mathrm{~nm}$. 
Ch. Niranjan Patra et al.: Design and evaluation of sustained release bilayer tablets of propranolol hydrochloride, Acta Pharm. 57 (2007) 479-489.

\section{Kinetic analysis of dissolution data}

The rate and mechanism of release of propranolol hydrochloride from the prepared bilayer tablets were analyzed by fitting the dissolution data into the zero-order equation (18):

$$
Q=k_{0} t
$$

where $Q$ is the amount of drug released at time $t$, and $k_{0}$ is the release rate constant, fitted to the first order equation (19):

$$
\ln (100-Q)=\ln 100-k_{1} t
$$

where $k_{1}$ is the release rate constant. The dissolution data was fitted to the Higuchi's equation (20)

$$
Q=k_{2} t^{1 / 2}
$$

where $k_{2}$ is the diffusion rate constant.

The dissolution data was also fitted to the well known equation (Korsmeyer equation), which is often used to describe the drug release behavior from polymeric systems (21):

$$
\log \left(M_{\mathrm{t}} / M_{\infty}\right)=\log k+n \log t
$$

where $M_{\mathrm{t}}$ is the amount of drug released at time $t, M_{\infty}$ is the amount of drug release after infinite time, $k$ is a release rate constant incorporating structural and geometric characteristics of the tablet and $n$ is the diffusional exponent indicative of the mechanism of drug release.

\section{FT-IR study}

Infrared spectrum was taken (FT-IR, Spectrum RX 1, Perkin Elmer Ltd, Swizerland) by scanning the sample in potassium bromide discs. The samples of pure drug and granules containing different polymers were scanned individually.

\section{Statistical analysis}

In vitro release data of propranolol hydrochloride from bilayer tablets of optimized formulations were subjected to the analysis of variance (ANOVA) at two different time intervals, $15 \mathrm{~min}$ and $12 \mathrm{~h}$. 


\section{RESULTS AND DISCUSSION}

The prepared bilayer tablets were evaluated for various physical properties. The bulk densities for the granules of various formulations ranged between $0.87 \pm 0.14$ and $2.42 \pm 0.42 \mathrm{~g} \mathrm{~mL}^{-1}$, as determined by the tap method. This value of bulk density indicates of good packing character. The compressibility index (CI) for all the formulations was found to be below $15 \%$, indicating desirable flow properties (14). The flow properties of granules were further analyzed by determining the angle of repose for all granules; it ranged between $21.32 \pm 0.58$ to $25.03 \pm 0.23^{\circ}$. The value indicates good flow property (15) of granules with Eudragit RLPO, Eudragit RSPO and ethylcellulose as matrix material.

All the batches of tablets were produced under similar conditions to avoid processing variables. Mass of the bilayer tablets was $201 \pm 12 \mathrm{mg}$, hardness was $5.2 \pm 1.2 \mathrm{~kg}$ $\mathrm{cm}^{-2}$ and thickness was $2.9 \pm 0.1 \mathrm{~mm}$. The percentage friability of all the formulations was $0.5 \pm 0.3 \%$. Values of the hardness test and percent friability indicate good handling properties of the prepared bilayer tablets. The drug content uniformity in the bilayer matrix tablets was $96.5 \pm 4.9 \%$.

The FT-IR spectrum of propranolol hydrochloride, shown in Fig. 1, revealed the presence of peaks at $2965.1 \mathrm{~cm}^{-1}$ due to the presence of a secondary amine group, peaks at $3283.7 \mathrm{~cm}^{-1}$ due to the hydroxyl group (secondary), the aryl alkyl ether displayed a stretching band at $1268 \mathrm{~cm}^{-1}$ and the peak at $797.9 \mathrm{~cm}^{-1}$ was due to $\alpha$-substituted naphthalene. The FT-IR spectra of propranolol hydrochloride granules containing different types of polymer showed a broadening of peaks at $3283 \mathrm{~cm}^{-1}$ frequency due to extensive hydrogen bonding. Major frequencies of functional groups of pure drug remain intact in granules containing different polymers; hence, there is no major interaction between the drug and polymers used in the study.

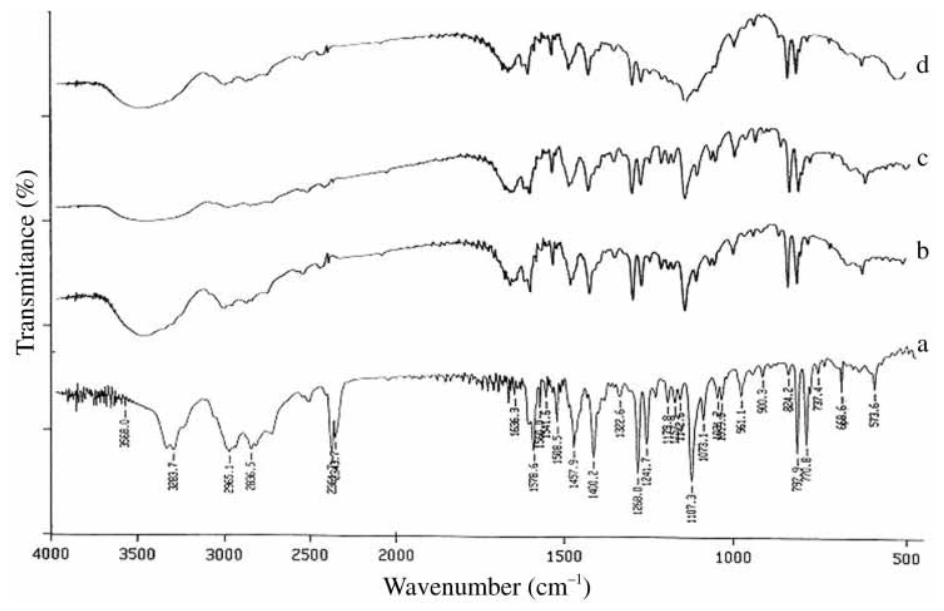

Fig. 1. FT-IR spectra of pure propranolol hydrochloride (a) and propranolol hydrochloride granules containing different polymers: ethylcellulose (b), Eudragit RSPO (c), and Eudragit RLPO (d). 
The release of propranolol hydrochloride from the prepared formulations was analyzed by plotting the cumulative percent drug released vs. time as shown in Figs. 2a-c. Simple visual observation of the plot shows an initial burst effect. From all the formulations, over $30 \%$ of the propranolol hydrochloride was released within the first $15 \mathrm{~min}$ of the dissolution study. This initial high amount of propranolol hydrochloride release can be attributed the immediate release layer of the formulation. Further release of propranolol hydrochloride was studied for $12 \mathrm{~h}$.

Ethylcellulose has been used as release retardant polymer in controlled release dosage forms $(8,22,23)$. EC reduces the drug release due to a reduction in the penetration of the solvent molecules into the system because of the hydrophobic nature of ethylcellulose present on the surface of the tablet, i.e. the rate of release is controlled by the permeability of matrix structure (24). As the proportion of ethylcellulose increase, the release process of propranolol hydrochloride decreares (Fig. 2a). Fig. 2a shows that formulation EC 1:0.5 could not sustain the release beyond $7 \mathrm{~h}$ whereas formulations EC 1:1 and EC 1:1.5 showed the desired release profile over the test period of $12 \mathrm{~h}$. Therefore, formulation EC 1:1 was selected as the optimized formulation keeping in view the minimum

a)

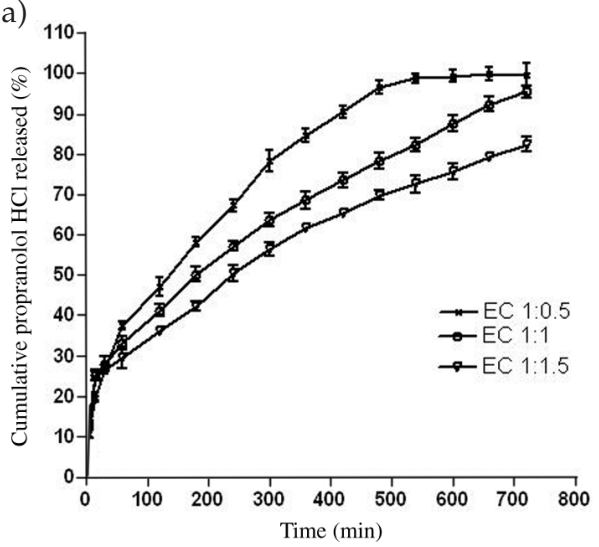

c)

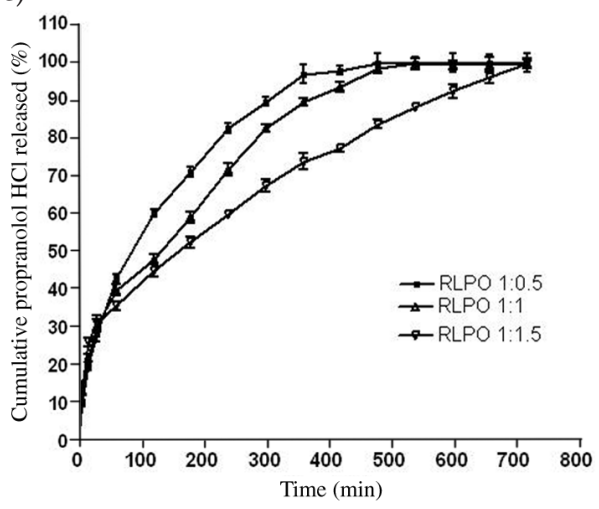

b)

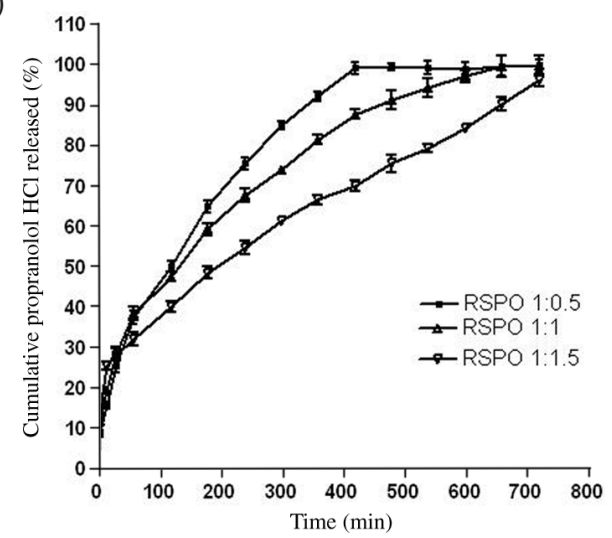

Fig. 2. Cumulative propranolol hydrochloride released $v s$. time (mean $\pm S D, n=3$ ) from: a) EC, b) Eudragit RSPO, c) Eudragit RLPO. 


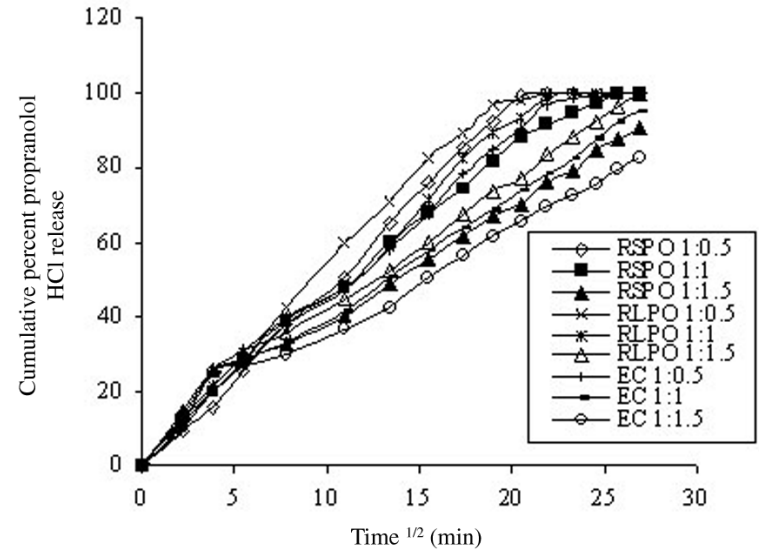

Fig. 3. Higuchi plot for cumulative percent propranolol hydrochloride released vs. square root of time (mean $\pm S D, n=3)$.

amount of ethylcellulose required to sustain the release for a period of $12 \mathrm{~h}$. In this selected formulation, the calculated regression coefficients for Higuchi, zero order and first order models were $0.991,0.967$ and 0.945 , respectively. Therefore, the release seems to fit the Higuchi model (Fig. 3). To explore the release pattern, results of the in vitro dissolution data were fitted to the Korsmeyer and Peppas equation (25), which characterizes the transport mechanism. The value of release exponent $(n)$ for the optimized formulation EC 1:1 was 0.585, indicating release governed by non-Fickian diffusion (Fig. 4).

Similarly, formulations containing Eudragit RSPO (RSPO 1:0.5 and RSPO 1:1) and Eudragit RLPO (RLPO 1:0.5 and RLPO 1:1) were unable to sustain the release of drug for the desired period of $12 \mathrm{~h}$ (Fig. 2b,c). However, the formulation RSPO 1:1.5 and RLPO $1: 1.5$ could sustain the release for $12 \mathrm{~h}$. Hence, these two were selected as optimized formulations. The calculated regression coefficients for Higuchi, zero order and first order models for the last two were $0.988,0.979$ and 0.952 , and $0.988,0.979$ and 0.952 , respectively. Therefore, the release seems to fit the Higuchi model (Fig. 3). The Korsmeyer and

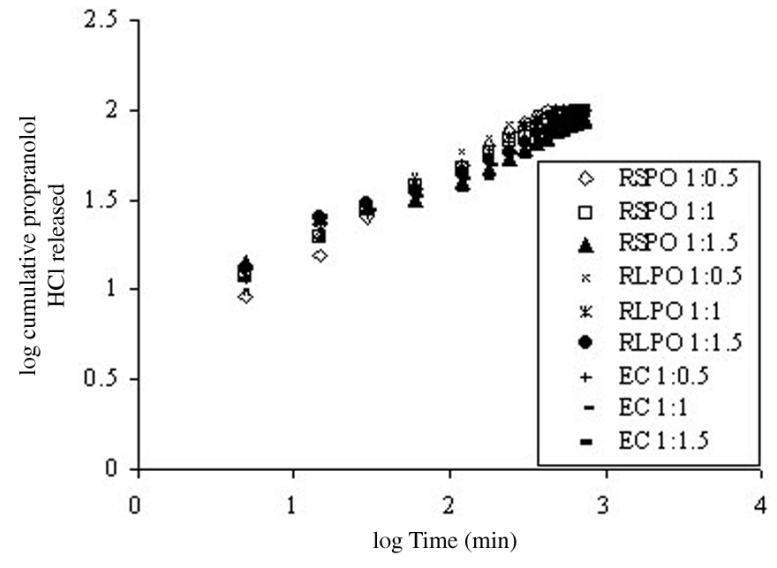

Fig. 4. Koresmeyer and Peppas plot of $\log$ of propranolol hydrochloride released $v s$. $\log$ of time (mean $\pm S D$, $n=3)$. 
Peppas release exponent $(n)$ for formulation RSPO 1:1.5 was 0.610 and for RLPO 1:1.5 0.604 , indicating release governed by non-Fickian diffusion (Fig. 4). The drug release from formulation RSPO 1:1.5 was less compared to RLPO 1:1.5, because Eudragit RLPO tends to swell more than Eudragit RSPO in aqueous medium (26, 27). Also, Eudragit RLPO is more permeable to aqueous medium than Eudragit RSPO (28).

All the formulations prepared with ethycellulose, Eudragit RSPO and Eudragit RLPO predominantly followed the Higuchi model and non-Fickian diffusion after the initial burst release. In all the three polymers, permeability to water was the common rate controlling factor.

Analysis of variance (ANOVA) showed no significant difference in the amount of drug released after 15 min from optimized formulations EC 1:1, RSPO 1:1.5 and RLPO 1:1.5; however, significant differences $(p<0.05)$ were observed for the amount of drug released after $12 \mathrm{~h}$ from the same formulations.

\section{CONCLUSIONS}

The present research was carried out to develop a bilayer tablet of propranolol hydrochloride using superdisintegrant sodium starch glycolate for the fast release layer and ethylcellulose, Eudragit RLPO and Eudragit RSPO for the sustaining layer. Bilayer tablets showed an initial burst effect to provide the loading dose of the drug, followed by sustained release for $12 \mathrm{~h}$, indicating a promising potential of the propranolol hydrochloride bilayer tablet as an alternative to the conventional dosage form.

\section{REFERENCES}

1. Martindale, The Extra Pharmacopoeia, 31 st ed., The Pharmaceutical Press, London 1996, pp. 936937.

2. M. J. Serlin, M. L. Orme, M. Maciver, G. J. Green, R. G. Sibeon and A. M. Beckenridge, Pharmacodynamics and pharmacokinetics of conventional and long acting propranolol in patients with moderate hypertension, J. Clin. Pharmcol. 15 (1983) 519-526.

3. B. Taylan, Y. Capan, O. Guven, S. Kes and A. A. Hincal, Design and evaluation of sustained release and buccal adhesive propranolol hydrochloride tablets, J. Control. Rel. 38 (1996) 11-20; DOI: 10.1016/0168-3654(95)00094-1.

4. M. A. Abraham and A. Shirwaikar, Formulation of multilayered sustained release tablets using insoluble matrix system, Indian J. Pharm. Sci. 59 (1997) 312-315.

5. J. P. Vercammen, D. Dauwe and P. Brioen, Possibility of use of Eudragit RS as a sustained release matrix agent for the incorporation of water soluble active compounds at high percentages, STP Pharma. Sci. 7 (1997) 491-497.

6. S. B. Jayaswa, K. D. Gode and S. K. Khanna, Sustained release tablet formulation of propranolol hydrochloride with Eudragit, Aust. J. Pharm. Sci. 9 (1980) 22-26.

7. S. N. Makhija and P. R. Vavia, Once daily sustained release tablets of venlafaxine, a novel antidepressant, Eur. J. Pharm. Biopharm. 54 (2002) 9-15; DOI: 10.1016/S0939-6411 (02) 00049-8. 
Ch. Niranjan Patra et al:: Design and evaluation of sustained release bilayer tablets of propranolol hydrochloride, Acta Pharm. $\mathbf{5 7}$ (2007) 479-489.

8. P. R. Katikaneni, S. M. Upadrashta, S. H. Neau and A. K. Mitra, Ethylcellulose matrix controlled release tablets of a water soluble drug, Int. J. Pharm. 123 (1995) 119-125; DOI: 10.1016/0378-5173 (95)00060-V.

9. G. Shlieout and G. Zessin, Investigation of ethylcellulose as a matrix former and a new method to regard and evaluate the compaction data, Drug Dev. Ind. Pharm. 22 (1996) 313-319.

10. I. Pather, I. Russell, J. A. Syce and S. H. Neau, Sustained release theophylline tablets by direct compression, Part 1: formulation and in vitro testing, Int. J. Pharm. 164 (1998) 1-10; DOI: 10.1016/ S0378-5173(97)00348-7.

11. S. M. Upadrashta, P. R. Katikaneni, G. A. Hileman and P. R. Keshary, Direct compression controlled release tablets using ethylcellulose matrices, Drug Dev. Ind. Pharm. 199 (1993) 449-460.

12. E. A. Rawlins, Formulation, in Bentley's Text Book of Pharmaceutics, $8^{\text {th }}$ ed., Bailliere Tindall, London 1996, pp. 663-666.

13. K. E. Thummel, D. D. Shen, N. Isoherranen and H. E. Smith, Design and Optimization of Dosage Regimens; Pharmacokinetic Data, in Goodman and Gilman's The Pharmacological Basis of Therapeutics, $11^{\text {th }}$ ed. (Eds. L. L. Bruton, J. S. Laro and K. L. Parker), McGraw-Hill Medical Publishing Division, London 2006, pp. 1863.

14. J. Staniforth, Powder Flow, in Pharmaceutics - the Science of Dosage Form Design, $2^{\text {nd }}$ ed. (Ed. M. E. Aulton), Churchill Livingstone, London 2002, pp. 207-208.

15. A. Martin, P. Bustamante and A. Chun, Micromeritics, in Physical Pharmacy-Physical Chemical Principles in the Pharmaceutical Sciences, $4^{\text {th }}$ ed., Lippincott Williams and Wilkins, Baltimore 2002, pp. 446-448.

16. H. C. Ansel, L. V. Allen and N. G. Popovich, Capsules and Tablets, in Pharmaceutical Dosage Forms and Drug Delivery Systems, $7^{\text {th }}$ ed., Lippincott Williams \& Wilkins, Philadelphia 2002, pp. 204-209.

17. USP 24/NF 19, USP Convention, Rockville 1999, pp. 1429.

18. H. A. Merchant, H. M. Shoaib, J. Tazeen and R. I. Yousuf, Once-daily tablet formulation and in vitro release evaluation of cefpodoxime using hydroxypropyl methylcellulose: A technical note, AAPS Pharm. Sci. Tech. 7 (2006) Article 78; DOI: 10.1028/pt 070378.

19. D. W. Bourne, Pharmacokinetics, in Modern Pharmaceutics, $4^{\text {th }}$ ed. (Eds. G. S. Banker and C. T. Rhodes), Marcel Dekker, New York 2002, pp. 67-92.

20. T. Higuchi, Mechanism of sustained action medication, J. Pharm. Sci. 52 (1963) 1145-1149.

21. R. W. Korsmeyer, R. Gurny, E. Docler, P. Buri and N. A. Peppas, Mechanism of solute release from porous hydrophilic polymers, Int. J. Pharm. 15 (1983) 25-35; DOI: 10.1016/0378-5173(83) 90064-9.

22. A. Stamm and J. C. Tritsch, Some consideration on the liberation of drugs from inert matrices, Drug Dev. Ind. Pharm. 12 (1986) 2337-2353.

23. C. S. Lafuente, M. T. Fauci, M. F. Arevelo, J. A. Fuentes, A. M. Rabasco and P. Mura, Development of sustained release tablets of didanosine containing methacrylic and ethylcellulose polymers, Int. J. Pharm. 234 (2002) 213-221; DOI. 10.1016/S0378-5173(10)00962-0.

24. M. Guyot and F. Fawaz, Nifedipine loaded polymeric microspheres: preparation and physical characteristics, Int. J. Pharm. 175 (1998) 61-74; DOI: 10.1016/S0378-5173(98)00253-1.

25. N. A. Peppas, Analysis of Fickian and non Fickian drug release from polymers, Pharm. Acta Helv. 60 (1985) 110-111.

26. J. Akubuga, Preparation and evaluation of controlled release furosemide microspheres by spherical crystallization, Int. J. Pharm. 53 (1989) 99-105; DOI: 10.1016/0378-5173(89)90233-0.

27. Y. Kawashima, T. Niwa, T. Handa, H. Takeuchi, T. Iwamoto and K. Itoh, Preparation of controlled release microspheres of ibuprofen with acrylic polymers by a novel quasi-emulsion solvent diffusion, J. Pharm. Sci. 78 (1989) 68-72.

28. S. Haznedar and B. Dortunc, Preparation and in vitro evaluation of eudragit microspheres containing acetazolamide, Int. J. Pharm. 269 (2004) 131-140; DOI: 10.1016/J.ijpharm.2003.09.015. 
Ch. Niranjan Patra et al.: Design and evaluation of sustained release bilayer tablets of propranolol hydrochloride, Acta Pharm. 57 (2007) 479-489.

\section{Razvoj i vrednovanje dvoslojnih tableta propranolol hidroklorida}

CHINAM NIRANJAN PATRA, ARETHI BHARANI KUMAR, HEMANT KUMAR PANDIT, SATYA PRAKASH SINGH i MEDURI VIMALA DEVI

U radu je opisan razvoj dvoslojnih tableta propranolol hidroklorida, koristeći superdezintegrator škrob glikolat natrij u sloju za brzo oslobađanje i polimere koji se ne miješaju s vodom (etilceluloza, Eudragit RLPO i Eudragit RSPO) u sloju za usporeno oslobađanje. In vitro oslobađanje praćeno je u USP aparatu I te je uočeno početno naglo oslobađanje ljekovite tvari iza kojeg slijedi polagano oslobađanje tijekom 12 sati. In vitro kinetika oslobađanja prati Higouchijev model, dok mehanizam kontroliranog oslobađanja ne slijedi Fickov zakon poslije početnog naglog oslobađanja. FT-IR studije ukazuju da nema interakcije između ljekovite tvari i polimera upotrebljenih u oblikovanju. Statistička analiza (ANOVA) nije pokazala značajne razlike u kumulativnoj količini oslobođenog lijeka iz optimiranih formulacija poslije 15 minuta, ali polije $12 \mathrm{~h}$ još se ta količina značajno razlikovala $(p<0.05)$.

Ključne riječi: propranolol hidroklorid, dvoslojne tablete, škrob glikolat natrij, polimeri koji se ne miješaju s vodom, statistička analiza

P.G. Department of Pharmaceutics, College of Pharmaceutical Sciences, Berhampur-760002, Orissa, India 